\title{
O MUNDO ZOO EM CLARICE LISPECTOR
}

\author{
Lorena Pereira Silva* \\ Maria das Graças Fonseca Andrade
}

RESUMO: Autora de obras importantes que reverberam até hoje, tais como Perto do coração selvagem, A paixão segundo G.H., Agua Viva e $A$ bora da estrela, Clarice Lispector é um dos nomes de maior relevância no cenário da literatura brasileira. Desde suas primeiras composições, a autora demonstra uma relação extremamente próxima e empática com os animais chegando, muitas vezes, a legar-lhes total protagonismo. Lispector, engenhosamente, constrói suas narrativas de modo a aproximar humano e animal, esferas aparentemente tão distintas entre si. Interessa-nos, aqui, analisar como isso aparece em Uma aprendizagem on O livro dos prazeres - sexto romance de sua carreira. Para tanto, traçaremos um percurso capaz de assegurar ao leitor a aproximação homem-animal, bem como suas reincidências, nos escritos claricianos. Com esse intuito, abordaremos alguns de seus contos, crônicas e livros dedicados ao público infantil, nos quais o humano é representado através do animal e que, por essa razão, entendemos como pertinentes, dados os objetivos deste artigo.

PALAVRAS-CHAVE: Animais; Clarice Lispector; Humano; Representação; Uma aprendizagem ou O livro dos prazeres.

\section{Clarice Lispector: Alguns contos e romances}

Falar sobre Clarice Lispector é, antes de qualquer coisa, reconhecer que seus textos - não obstante formas e temas - fogem do óbvio. A autora é conhecida pelos mergulhos profundos de suas personagens em si mesmas, sejam elas protagonistas ou não. Seus escritos recorrentemente tratam de angústias, devaneios, percepções de mundo, relações interpessoais e a fragilidade de seus elos, reflexões cotidianas e, aparentemente corriqueiras, sem, contudo, incidir no que porventura viesse a soar banal.

\footnotetext{
* Mestranda em Letras: Cultura, Educação e Linguagens pela Universidade Estadual do Sudoeste da Bahia (Uesb). ** Professora Titular da Universidade Estadual do Sudoeste da Bahia (Uesb). Doutora em Letras: Estudos Literários pela Universidade Federal de Minas Gerais (UFMG).
} 
No ano em que antecede o centenário de seu nascimento nada mais justo que lhe prestar as devidas honrarias e trazer à luz uma discussão, que nos parece intrigante e pertinente, sobre a temática animal em alguns de seus contos, a saber: "Uma galinha”, “O búfalo", "Macacos", "Uma esperança", "O ovo e a galinha" e "Seco estudo de cavalos"; bem como de alguns romances: Perto do coração selvagem (1943), A paixão segundo G.H. (1964) e o livro que é objeto de estudo para essa pesquisa Uma aprendizagem ou O livro dos prazeres (1969); cuja compreensão de suas personagens centrais exige - mesmo na atualidade - perspicácia acrescida de uma leitura mais cautelosa por parte do seu público leitor. Dito isso, o que se pretende, portanto, é demonstrar como - por meio da escrita - Clarice Lispector despertou, desde suas primeiras publicações, certo tipo de inquietação tanto no público leitor quanto na crítica literária ao tratar de emoções humanas através dos mais distintos animais.

Antes de se tornar uma das maiores escritoras brasileiras de todos os tempos por obras que reverberam até os dias de hoje, como Perto do coração selvagem (1943), A paixão segundo G.H. (1964), Água viva (1973) e A hora da estrela (1977); Clarice Lispector teve uma formação na área de Direito e de Jornalismo. Em meados da década de 1970 - após afastarse do ofício de colunista do Jornal do Brasil - passou a se dedicar, concomitantemente, à tradução de obras diversas.

Desde sua infância no Nordeste - em Maceió e Recife - aventurara-se, sem qualquer tipo de compromisso e/ou pretensões futuras, a compor alguns pequenos contos. $\mathrm{Na}$ tentativa de que fossem publicados, ela incansavelmente, enviava-os aos jornais e revistas de sua época. Situação da qual recordaria anos mais tarde, em 1964, em A legião estrangeira, com o título "Era uma vez". Depois tornou a ser publicada em dia 19 de fevereiro de 1972 , na coluna que mantivera no Jornal do Brasil com o título "Ainda impossível",

[...] eu gostaria mesmo era de poder um dia afinal escrever uma história que começasse assim: "era uma vez..." Para crianças? perguntaram. Não, para adultos mesmo, respondi já distraída, ocupada em me lembrar de minhas primeiras histórias aos sete anos, todas começando com "era uma vez". Eu as enviava para a página infantil das quintas-feiras do jornal de Recife, e nenhuma, mas nenhuma mesmo, foi jamais publicada. E mesmo então era fácil de ver por quê. (LISPECTOR, 1994, p. 437) 
Mal sabia a menina Clarice que tal dificuldade em se dar a ver de modo compreensível se estenderia até a idade adulta. Perto do coração selvagem, seu romance inaugural, recebeu diversas negativas por parte da comunidade editorial daquele período, como salienta Maria das Graças F. Andrade:

[...] seu romance de estreia foi recusado por diversas editoras (a história da infância se repetia, seu texto era rejeitado devido ao estranhamento que ele causava nos críticos que o leram: "Olha, eu não entendi seu livro, não”) e só atingiu a publicação com Clarice tendo que abrir mão de seus direitos autorais. (ANDRADE, 2007, p. 20)

As recusas foram muitas, pois os periódicos que se dedicavam à publicação de textos infantis buscavam um tipo comum de texto fantasioso e/ou fabulações e, desde tenra idade, Clarice empenhara-se em demonstrar algo para além do explícito, algo que ela mesma mais tarde reconheceu: "Os outros diziam assim: era uma vez, e isso e aquilo... e os meus eram sensações.” (LISPECTOR, 2005, p. 9)

Anos mais tarde, enquanto se dedicava ao ofício de jornalista, é que a jovem autora viu, então, a oportunidade de voltar a encaminhar para os jornais e revistas alguns de seus contos na esperança de que fossem, finalmente, publicados. Em 25 de maio de 1940, no periódico Pan, é que se torna público, oficialmente, o primeiro texto assinado por Clarice intitulado "O triunfo". Naquele mesmo ano, e no seguinte, outros contos foram publicados em diferentes veículos de grande circulação, a saber: "Eu e Jimmy” (1940), “Trecho” (1941) e "Cartas a Hermengardo" (1941) 28. Vale aqui ressaltar que nos anos de 1940-41, a autora escreveu outros contos, foram eles: "O delírio” (1940), "História interrompida” (1940), “A fuga" (1940), "Gertrudes pede um conselho" (1941), “Obsessão" (1941) e "Mais dois bêbados" (1941) ${ }^{29}$, que compõem a parte I do livro $A$ bela e a fera, publicado postumamente

\footnotetext{
${ }^{28}$ Cf. Outros escritos, 2005, p. 10.

${ }^{29}$ Cf. Clarice Lispector. Todos os contos, 2016, p. 649.
} 
em 1979. Em nota que precede a leitura desses, ela esclarece ao leitor: "Este livro de contos foi escrito em 1940-1941. Nunca publicado” (LISPECTOR, 1999, p. 7).

Conforme o que fora dito anteriormente, as personagens de Lispector tendem a mergulhos profundos em si mesmas. Questões das mais diferentes naturezas são tratadas em seus textos, mas é a uma, em especial, que se pretende abordar mais detidamente nessa seção: a representação, por vezes, de características bastante peculiares dessas personagens por meio de animais, pois, como salienta Evando Nascimento:

A literatura de Clarice tem ajudado a questionar os limites do humano, na medida em que traz para seu espaço formas concorrentes em relação à tradição, tais como animais e objetos, texturas, paisagens, cores, trechos musicais, ruídos e silêncios. (NASCIMENTO, 2011, p. 129, grifo nosso)

Para que possamos compreender melhor como isso aparece em seus escritos precisamos ter em mente aquilo que Roger Chartier - historiador francês dedicado a estudos e pesquisas na área de: história da cultura, do livro, da edição e da leitura como práticas sociais -, tendo por base os estudos de Antoine Furetière, afirma sobre o processo de representação:

As definições antigas do termo (por exemplo, a do dicionário de Furetière) manifestam a tensão entre duas famílias de sentidos: por um lado, a representação como dando a ver uma coisa ausente, o que supõe uma distinção radical entre aquilo que representa e aquilo que é representado; por outro, a representação como exibição de uma presença, como apresentação pública de algo ou de alguém. No primeiro sentido, a representação é instrumento de um conhecimento mediato que faz ver um objeto ausente através da sua substituição por uma "imagem" capaz de o reconstruir em memória e de o figurar tal como ele é. [...] Outras, porém, são pensadas num registro diferente o da relação simbólica que, para Furetière, consiste na $<<$ representação de um pouco de moral através das imagens ou das propriedades das coisas naturais [...] O leão é o símbolo do valor; a esfera, o da inconstância; o pelicano, o do amor paternal >>.Uma relação compreensível é, então, postulada entre o signo visível e o referente por ele significado - o que não quer dizer que seja necessariamente estável e unívoca. (CHARTIER, 2002, p. 20-21) 
Dito isso, o que visamos é buscar um caminho para compreender a representação, da qual Clarice Lispector muitas vezes lança mão em seus textos, como um recurso expressivo. Em outras palavras, a representação é um campo amplo e dentro dela existe o campo do imaginário. Os textos e as obras enquanto práticas discursivas não têm um sentido intrínseco, absoluto, único. A leitura, bem como a produção discursiva, é uma prática que, plural e contraditoriamente, dá significado ao mundo.

Em 1943, aos 23 anos de idade, Clarice Lispector lança seu primeiro romance intitulado Perto do coração selvagem. O livro que inaugura sua exitosa carreira no meio literário é também aquele que primeiro vai trazer à luz a ligação da escritora com o universo dos animais e toda a complexidade de não mais entendê-los como o extremo oposto de nós humanos:

O animal não é um antepassado bárbaro, uma espécie atrasada ou anterior na cadeia evolutiva, um parente remoto de quem é preciso tomar distância em prol de um aperfeiçoamento da espécie humana, mas sim um espelho e um par, outra vida submersa nas vicissitudes da modernidade, subjugada e alheia a todo relato teleológico e evolucionista. (BRAVO, 2011, p. 238-239)

Já nas primeiras páginas de Perto do coração selvagem, observa-se que a personagem principal, Joana, possui uma relação muito próxima e compassiva com as galinhas, às quais passa a observar cuidadosamente. Para ela, existe algo de triste na sina de se nascer e ser galinha nesse mundo, em razão de elas possuírem uma vida breve e predestinada.

Isso nos remete a outros dois textos da autora: o primeiro é o conto "Uma galinha", publicado em 1952, juntamente com outros cinco contos na pequena coletânea intitulada Alguns contos e em Laços de família, publicado em julho em 1960, no Rio de Janeiro, pela Livraria Francisco Alves e, posteriormente, em A imitação da rosa, em 1973; e o segundo é a crônica intitulada "Nossa Truculência" que fora publicada no Jornal do Brasil, em 13 de dezembro de 1969 e, posteriormente, em Visão do esplendor: impressões leves, em 1975.

Em "Uma galinha”, a protagonista é, como o título sinaliza, uma galinha que através de um voo desajeitado busca escapar do seu destino trágico: ser servida num almoço de 
domingo. Mas, em se tratando de Clarice Lispector, não se pode incorrer no erro primário de achar que o conto trate apenas da fuga frustrada de uma galinha. É necessário sempre ler as entrelinhas, pois, conforme aconselha a própria escritora: “Mas já que se há de escrever, que ao menos não se esmaguem com palavras as entrelinhas.” (LISPECTOR, 1992, p. 20). Posteriormente, complementa:

Então escrever é um modo de quem tem a palavra como isca: a palavra pescando o que não é palavra. Quando essa não palavra morde a isca, a coisa se escreveu. Uma vez que se pescou a entrelinha, podia-se com alívio jogar a palavra fora. Mas aí cessa a analogia: a não palavra, ao morder a isca, incorporou-a. O que salva então é ler "distraidamente". (LISPECTOR, 1992, p. 34)

Talvez, o que o salve o leitor da falta de sentido seja tomar o texto clariciano tal como ele foi concebido: de modo distraído. Então, "ler distraidamente", desviando-se das palavras (das iscas), e atentando para as entrelinhas, (as não palavras) porque, conforme a própria escritora as coisas só acontecem quando estamos distraídos.

Em tese intitulada Da escrita de si à escrita fora de si: uma leitura de Objeto gritante e Água viva de Clarice Lispector, Maria das Graças Fonseca Andrade (2007, p. 186-187) chama a atenção exatamente para o fato de que é preciso estar um pouco fora de si, um tanto alheio, desconcentrado, para conseguir ler o texto no qual a autora vale-se das palavras não para dizer, mas para conservar bem dito e bendito o silêncio.

Dito isso, é possível afirmar que o artifício do qual a autora lança mão é o de permitir que seu leitor complete os sentidos daquilo que não está inscrito explicitamente em seus textos. Não só escreve bem aquele que domina o bom uso da língua e, por intermédio dela, consegue elaborar/construir uma boa trama. Mas, principalmente, aquele que através da palavra é hábil em transmitir sensações ao seu leitor, em escrever em tom menor, em fazer a palavras silenciar. Pois, o escritor “[...] enquanto escreve, deve ter um olhar não apenas voltado para a língua e suas regras gramaticais, mas também para si mesmo, para aquilo que ele, profundamente, sente" (ANDRADE, 2007, p. 157) e que, por meio da palavra, busca exprimir. 
A narrativa apresenta três personagens centrais, sendo eles: a galinha - protagonista da história - aquela que conduz o jogo e confere dinamismo à trama; o pai - assumindo o papel de antagonista, ou seja, aquele que se faz necessário para que haja o conflito; e, por fim, mas não menos importante, a mãe - cujo atributo conferido é o de ser apenas a cozinheira e, aparentemente, possuir certo ar de cansaço - não se sabe se da vida como um todo e/ou da condição de mulher e mãe.

A listagem de características psicológicas que a autora lança mão no esforço de delimitar o perfil da galinha é determinante para que possamos identificar que esta não se trata apenas de um animal - para tanto bastava limitar-se a elencar seus atributos físicos e específicos. Ao definir a galinha como "afobada”, "hesitante”, “desajeitada”, "tímida”, “estúpida" e afins, o que se vê é a tentativa de humanização desse animal. Ou seja, à galinha é conferido um novo patamar de compreensão; pois, tais sentimentos e sensações são habitualmente atribuídos aos humanos.

Em contrapartida, há a figura do pai. Altiva, imponente e definida por Clarice como “um caçador adormecido". É preciso ter em mente que o jogo de palavras na literatura clariciana obedece a uma intenção. E, nesse caso, é a de tornar claro o lugar que o feminino e o masculino ocupam socialmente. O homem em seu eterno pedestal, ao passo que à mulher - encerrado o período em que está apta para crescer e multiplicar - resta apenas o fado de servir. Isso pode ser contatado muito claramente nas palavras de Nascimento:

Certo "não-humano" clariciano leva a pensar diversas coisas, que listaria sinteticamente: a animalidade em contraste com a humanidade; o rebaixamento dos bichos à condição de fera; a redução da espécie (humana) ao gênero masculino (o Homem). (NASCIMENTO, 2011, p. 128)

Ao decidir-se por não legar nomes às personagens, a narrativa faz crer que não se trata de um caso isolado ou específico, mas no fatalismo de sermos todos nós. Desse modo, a figura da mulher - representada pela galinha - é aquela a quem desde cedo se ensina a cuidar e servir; a figura do homem - representada pelo pai - é aquele a quem se deve servir; 
e, por fim, o ovo - que a galinha acaba por colocar em meio ao susto de ter sido capturada - é a representação da maternidade com o ônus e bônus que ela traz junto a si.

Assim deturpada, a representação transforma-se em máquina de fabrico de repeito e de submissão, num instrumento que produz constrangimento interiorizado, que é necessário onde quer que falte o possível recurso a uma violência imediata. (CHARTIER, 2002, p. 22)

O segundo texto de Clarice sobre o qual faremos menção ao falar de sua complacência para com a condição animal da galinha é a crônica "Nossa truculência". Nela, a autora faz uma breve reflexão sobre o conflito de interesses que regem a natureza do ser humano. Por um lado, o de sermos incapazes de matar um animal com as próprias mãos, mas em contrapartida o de nos regozijarmos ao devorar um prato cujo ingrediente principal é o dito animal - ela utiliza como exemplo, galinha ao molho pardo. Curioso é que em outros textos de sua autoria, como veremos, mais de uma vez ela fará alusão a esse prato.

A crônica em voga nos faz refletir sobre uma questão de extrema importância nos dias de hoje e gera um debate interessante sobre a seguinte indagação: onde, de fato, reside a selvageria? Mas, sobre isso, falaremos com mais afinco em outra seção. Por ora, o que temos de compreender é que, como se sabe, em primeira instância o homem é animal, apesar de ele - como vimos anteriormente - muito rejeitar essa condição. Logo, por que o mesmo homem que é capaz de condenar o assassinato (de sua espécie/do seu igual) parece não dar muita importância para a vida/morte dos animais?

O título da crônica muito diz sobre a maneira errônea como o homem compreende o espaço e os demais viventes ao seu redor. É necessário não esquecermos que, na condição de animal, estamos sujeitos a reagir conforme nossos piores instintos.

Com o animal, as relações são, sobretudo, transversais, ou seja, o animal é considerado o oposto do homem, mas ao mesmo tempo uma espécie de simbolização do próprio homem. Na acepção comum, simboliza o que o homem teria de mais baixo, de mais instintivo, de mais rústico ou rude na sua existência. Por isso mesmo, o animal para nós é o grande outro da nossa cultura. (NUNES, 2011, p. 13) 
Apesar de toda falácia sobre sermos evoluídos, superiores, racionais, justos e assim por diante, a verdade é que somos canibais (por vezes, de nós mesmos). Comemos sem remorso outros seres vivos e, para minimizar tal atitude, agarramo-nos ao fato de não ser um outro ser humano. Por mais que tentemos nos distanciar da ideia de nos assemelharmos aos animais - por julgar-lhes inferiores e/ou menos importantes - muito há que se apreender sobre o modo como esses vivem e conduzem, a despeito de nós, sua existência. Um animal não maltrata outro animal, escraviza ou exerce qualquer outro tipo de maldade ao seu bel prazer.

Schopenhauer faz alusões ferinas a respeito do tema. Nenhum animal maltrata apenas por maltratar, mas o homem sim, e nisso constitui o seu caráter demoníaco, muito mais grave do que o caráter simplesmente animal. (NUNES, 2011, p. 16)

Dito isso, fica bastante clara a marca que Clarice Lispector imprime em seus textos. Aquilo que seria, inicialmente, uma breve explanação sobre uma situação corriqueira e comum, na verdade, transforma-se numa crítica e reflexão sobre a sociedade. Em "Uma galinha”, temos a reflexão sobre os papéis da figura masculina e feminina - representados pela figura do pai e da galinha, respectivamente - bem como dos lugares de privilégio e imposição aos quais estão condicionados, tendo por base o gênero de cada um; e, em "Nossa truculência", há a ponderação sobre o falso moralismo que rege a raça humana envaidecida da sua autopercepção de animal superior e, por isso mesmo, detratora das demais manifestações de vida ocupantes do espaço natural em comum.

Regressemos, pois, à questão da reincidência da expressão "galinha ao molho pardo" e "nossa truculência" nos textos da escritora. Muito timidamente os temas de ambos os textos analisados aparecem no livro que fomenta essa pesquisa Uma aprendiragem on O Livro dos prazeres, publicado em 1969. Num diálogo que se estabelece entre as personagens principais da trama - Loreley e Ulisses - é retomado o assunto de que há pouco falamos:

- Não sei mais se no restaurante da Floresta da Tijuca tem galinha ao molho pardo, bem pardo por causa do sangue espesso que eles 
lá sabem preparar. Quando penso no gosto voraz com que comemos o sangue alheio, dou-me conta de nossa truculência, disse Ulisses.

- Eu também gosto, disse Lóri a meia-voz. Logo eu que seria incapaz de matar uma galinha, tanto gosto delas vivas, mexendo o pescoço feio e procurando minhocas. Não era melhor, quando formos lá, comer outra coisa? perguntou meio a medo. (LISPECTOR, 1998, p. 99)

Como vimos, há na literatura clariciana uma preocupação em diminuir o abismo que separa instâncias tão próximas como humano e animalidade. As palavras da autora evidenciam sua intenção de aparar as arestas que, por tantos e tantos anos, fincaram raízes na mentalidade ocidental de se idealizar superior a tudo e todos.

Outro texto bastante pertinente que abordará de forma oportuna a questão animal - ainda falando do mesmo animal, a galinha - é o livro A vida intima de Laura, publicado em 1974. Esse livro, diferentemente dos demais textos de que falamos, é dedicado ao público infantil e conta a história de vida de uma galinha chamada Laura. Tal como no conto "Uma galinha", aqui a história fala sobre o dia a dia em um quintal e, mais especificamente, sobre um animal em particular, a galinha Laura. Novamente há uma descrição depreciativa da personagem principal por parte da escritora. As palavras utilizadas para definir Laura são: "burra", "doida" e "sem jeito"; ao passo que o marido de Laura - o galo Luís - é descrito como um animal vaidoso, bonito e muito competente em suas funções.

Em suma, A vida intima de Laura vai contar a história de uma galinha, nem a mais bonita, nem a mais feia, mas que é muito boa em colocar ovos. Aqui, mais uma vez, podemos - tal como fizemos em "Uma galinha" - comparar características da personagem Laura e Luís com o papel do homem e da mulher na sociedade patriarcal. Sob esse sistema social, nascer homem significa nascer privilegiado e salvo, enquanto nascer mulher significa viver uma vida de desvantagens e subordinações, tudo em consequência de seus respectivos gêneros. Quaisquer que sejam os exercícios de suas funções - mesmo em pleno século XXI - é lastimoso pensar em: homens e mulheres realizando um mesmo ofício e sendo remunerados de maneira tão desigual; em mulheres que pelo simples fato de assim terem nascido 
terem seu direito à liberdade cerceado; em mulheres que, embora competentes e qualificadas para ocuparem os mais altos cargos, são oprimidas psicológica/moral e sexualmente; em mulheres que são demonizadas pelo contexto social ao rejeitar o que lhes é imposto por natureza, a maternidade e, por fim, mas não menos importante, em mulheres que cometem o pecado de envelhecer.

Pois, um dia, por Laura não mais colocar ovos como de costume, a cozinheira achou que ela estava ficando velha e sugeriu à D. Luiza matá-la e prepará-la ao molho pardo. É interessante observar que a autora introduz esse acontecimento com uma breve reflexão que também existentes em textos anteriores e aqui já citados: "É engraçado gostar de galinha viva mas ao mesmo tempo também gostar de comer galinha ao molho pardo. É que pessoas são uma gente meio esquisitona.” (LISPECTOR, 1991, p.13)

O livro supracitado, em virtude de ser dedicado ao público infantil, possui uma linguagem mais acessível, nem por isso deixa de imprimir o estilo característico dos escritos claricianos. Novamente aqui temos como força motriz a questão do animal como sujeito e não apenas como um indivíduo à margem de nós, seres humanos:

[...] o encontro/interação com o animal aponta para um movimento que não é necessariamente o da imitação, da alegoria ou o da transformação física do humano em animal não humano, mas um trespassamento íntimo das fronteiras, um salto radical à outra margem. (MACIEL, 2016, p. 110)

Publicado em Laços de família, em 1960, juntamente com a (re)publicação de "Uma galinha", o conto "O búfalo" é mais um exemplo do exercício da animalidade no ser humano que, tanto interesse despertou na autora. A história se passa no Jardim Zoológico e tem como personagens principais uma mulher - não nomeada pela escritora, e cuja indeterminação nos leva a crer que não se trata de um caso específico e/ou isolado - e um búfalo enjaulado.

A mulher resolve ir ao Jardim Zoológico após decepcionar-se afetivamente - um amor não correspondido - com o propósito de aprender a odiar. Segundo a personagem, ali seria o lugar ideal para que ela extraísse do universo zoo a carnificina de que necessitava 
para lidar com o sentimento de rejeição pelo qual estava passando. Mas, ao contrário do que se esperava, o que ela experimenta é amor genuíno, ou seja, o amor que não é movido por relações de interesse. Muito disso deve-se ao fato de ela ter ido ao Jardim Zoológico na primavera. Aliás, é pertinente ressaltar que o conto tem início com essa observação e se repete ao longo da narrativa "Mas era primavera" (LISPECTOR, 2016, p. 248).

A certa altura, no decorrer de seu passeio, a mulher faz a seguinte ponderação "Oh, Deus, quem será meu par nesse mundo?” (LISPECTOR, 2016, p. 250) e a resposta para seu questionamento lhe surgirá sob a aparência que ela jamais poderia supor: o búfalo.

No Jardim Zoológico, a protagonista tem contato com animais diversos, como: leão, leoa, girafa, hipopótamo, macacos, elefante, camelo, quati; mas, é justamente no encontro com o último animal, o búfalo, que ocorre a resignação. O contato visual que se estabelece entre as duas personagens centrais é o ponto chave da trama: "E os olhos do búfalo, os olhos olharam seus olhos. E uma palidez tão funda foi trocada que a mulher se entorpeceu dormente. De pé, em sono profundo. Olhos pequenos e vermelhos a olhavam. Os olhos do búfalo" (LISPECTOR, 2016, p. 257). De modo que, a partir daquela imagem soberana, imponente - que não deixa dúvida de sua força - prostrada frente à mulher, ela que só sabia amar encontra o búfalo que só sabia odiar. Algo manifesto no seguinte excerto: "Lentamente a mulher meneava a cabeça, espantada com o ódio com que o búfalo, tranquilo de ódio, a olhava" (LISPECTOR, 2016, p. 257). Ao longo de todo o conto a personagem diz-nos sobre "[...] o mal-estar que ela viera buscar.", "[...] a vontade de matar" (LISPECTOR, 2016, p. 250); “[...] a vontade atormentada de ódio como um desejo” (LISPECTOR, 2016, p. 252-253) e, dado o seu encontro com o animal, conclui que: "A morte zumbia nos seus ouvidos" (LISPECTOR, 2016, p. 255). Talvez, por isso, há que se levar em consideração o fato do animal búfalo não ter sido uma escolha aleatória da autora, pois conforme assegura Chevalier e Gheerbrant em Dicionário de símbolos, "A iconografia hindu faz dele a montaria e o emblema de Yama, divindade da morte. Igualmente, no Tibete o espírito da morte tem cabeça de búfalo" (CHEVALIER; GHEERBRANT, 1995, p. 137) 
Em outras palavras, a mulher que inicialmente fora ao Jardim Zoológico em busca de aprender com os animais, ou nas palavras da autora "[...] o mundo das bestas" (LISPECTOR, 2016, p. 253), a odiar - em virtude de uma desilusão amorosa - ao deparar-se com a figura do búfalo estabelece um vínculo inesperado.

Mais uma vez há que se chamar a atenção para a forma sutil com que a autora estabelece conexões entre o universo humano e animal. Em “O búfalo”, Clarice Lispector traz à tona a surpresa de uma personagem que se entrega a uma empatia silenciosa com o animal mais improvável (dos quais entra em contato no espaço do Jardim Zoológico), demonstrando a partir disso que:

[...] a literatura não é apenas um aparato de captura e confinamento: ela também produz e libera afetos, libera intensidades, faz com que um conjunto fuja. Porque há textos afetados, nos quais os animais não respondem a nenhum chamado, ou veem sem que sejam convocados. Trata-se de textos presos ou cativos de algum animal que está à espreita entre as linhas da escrita, um par de olhos brilhando incandescentes na noite da linguagem, a bordo da presença. Mais que uma perspectiva ou um olhar sobre o animal, trata-se de textos a partir dos quais um animal me olha e me afeta. (RODRÍGUEZ, 2011, p. 169)

Iremos nos deter, a partir de agora, sobre o conto "Macacos", publicado em A legião estrangeira em 1964. Nele são contadas as histórias de um gorila e da macaca Lisette. Respectivamente um macaco macho e uma fêmea e é, no mínimo, curiosa a distinção que a autora faz entre esses dois animais.

Em "Macacos", ao referir-se ao mico macho, a narradora o chama apenas de gorila - não lhe atribui um nome, sugerindo um distanciamento velado - e faz questão de deixar claro que se tratava de um presente extremamente inconveniente. Incomodara-lhe as proporções avantajadas do animal, sua falta de civilidade, sua algazarra - o que é natural, pois não se tratava de um animal doméstico - tanto, que ela passa a associar sua presença à de um homem, como podemos constatar nos seguintes trechos: "Quando me esquecia e en- 
trava distraída na área de serviço, o grande sobressalto: aquêle homem alegre ali." (LISPECTOR, 1964, p. 51); “[...] meninos de morro apareceram numa zoada feliz, levaram o homem que ria.” (LISPECTOR, 1964, p. 51-52) Mas o fato é que, com o auxílio de uma amiga, a narradora logo conseguiu se desfazer daquela sombra opressiva que tanto invadira sua intimidade.

Após o período de um ano, num passeio despretensioso pela orla de Copacabana, a narradora tomada por um sentimento de nostalgia, foi, e quase que imediatamente, atraída por uma macaca que estava à venda. Comprou-a e deu-lhe o nome de Lisette. Diferentemente do que ocorrera com o gorila no passado, com Lisette o afeiçoamento deu-se de maneira muito natural. Mesmo as palavras que a autora usara para se referir à macaquinha eram doces e gentis: "Era de uma tal delicadeza de ossos. De uma tal extrema doçura" (LISPECTOR, 1964, p. 52). Mas, tal qual fizera com o gorila, num dado momento a narradora associa Lisette a uma figura feminina, a quem define como "uma mulher em miniatura" (LISPECTOR, 1964, p. 52).

Quando pensamos no período em que fora publicado e nos artifícios utilizados para distinguir de forma tão peculiar o gorila e Lisette, constatamos que alguns

[...] textos contemporâneos aproximam o humano e o animal até o grau mais alto de intimidade possível, colocando-os, em certos momentos, em um mesmo nível de protagonismo e fazendo da distinção entre um e outro uma espécie de dobra em mutação constante, na qual a lógica do múltiplo escapa tanto da semelhança quanto da analogia, para se situar na descrição de uma região comum e compartilhada entre o animal e o humano. (GARRAMUÑO, 2011, p. 105)

O que se percebe no referido conto é a nítida distinção que Clarice Lispector faz entre os dois animais: o gorila e Lisette. O simples fato de nomear a macaca fêmea - atribuir um nome humano ao animal - é determinante para concebermos que isso é, ao mesmo tempo, humanizar o animal e bestializar o homem. O que se encontra expresso nas palavras de Maciel: 
Uma coisa é o escritor vestir o animal com roupas, dar-lhe hábitos, profissões e valores de gente, como nas fábulas e nos desenhos animados; outra é conferir-lhe capacidade de sofrer, solidarizar-se, ter emoções, demonstrar medo, lutar pela própria vida e exercitar sua inteligência. (MACIEL, 2016, p. 84)

As personagens Lisette e o gorila irão aparecer em outro livro de Lispector, mas agora um destinado ao público infantil e intitulado $A$ mulher que matou os peixes, publicado no ano de 1968. Por tratar-se de outro tipo de público-alvo, a abordagem que Clarice Lispector utiliza para contar a história se modifica, mas o enredo e os fatos em si, não. Novamente tem-se a figura incômoda do gorila muito bem definida nas seguintes palavras: "Esse macaco até parecia ter vida humana. Parecia com um homem maluco. Como ele fazia uma bagunça horrível na casa, resolvi dá-lo às crianças do morro que adoram micos” (LISPECTOR, 1993, p. 28); em contraste com amabilidade que a autora utiliza para se referir à macaquinha Lisete: “[...] uma miquinha muito suave e linda, que era muito pequena. Estava vestida com saia vermelha, e usava brincos e colares baianos. Era muito delicada conosco, e dormia o tempo todo" (LISPECTOR, 1993, p. 29).

Uma questão bastante relevante para ser mencionada nessa seção é o fato de que toda a literatura produzida por Clarice Lispector e voltada para os leitores mirins possuem uma ligação direta com o universo animal. Os animais ocupam o papel de protagonistas nos livros infantis de Clarice Lispector desde a publicação de seu primeiro livro infantil intitulado $O$ mistério do coelho pensante: (Uma história policial para crianças) e publicado em 1967; A mulher que matou os peixes no ano seguinte, em 1968; posteriormente acontece a publicação A vida intima de Laura, em 1974 e, dois lançamentos póstumos, Quase de verdade em 1978 e Como nasceram as estrelas, em 1987.

Ainda em $A$ mulher que matou os peixes, Clarice dará atenção aos insetos, àqueles animais que não temos na mais alta estima, ao contrário de gatos, cachorros, pássaros e afins. A eles ela irá se referir como "bichos naturais" sendo eles, no caso, as baratas e a lagartixa - que, naturalmente, não convidamos para adentrar o espaço de nossas casas, mas que mesmo assim insistem em visitá-las. Obviamente, por ser uma obra mais branda, a autora 
não fará aqui um mergulho psicológico profundo como em $A$ paixão segundo G.H. - livro que iremos tratar mais adiante.

Mas, a autora faz constar seu pesar em relação à condição desse animal - a barata, tão comum e natural, em expressões como: "Barata é outro bicho que me causa pena. Ninguém gosta dela, e todos querem matá-la”, (...) “Tenho pena das baratas porque ninguém tem vontade de ser bom com elas. Elas só são amadas por outras baratas” (LISPECTOR, 1993, p. 14). E, num movimento oposto, fala com menos pesar e uma tímida empatia sobre as lagartixas: "São engraçadas e não fazem mal nenhum. Pelo contrário: elas adoram comer moscas e mosquitos, e assim limpam minha casa toda" (p. 14) e "A lagartixa, que é minha grande amiga, me ajuda com muita alegria porque mosquito para ela é sobremesa” (p. 18).

Por fim, queremos nos ater ao conto "Uma esperança", publicado em Felicidade clandestina, em 1971. O conto versa sobre uma esperança que, inesperadamente, aparecera na casa da narradora. Mas, a expressão acaba se desdobrando tanto sobre o inseto, de fato a esperança, quanto sobre o sentimento de se ter esperança. O texto prossegue nessa oscilação entre a coisa concreta, o inseto, e a coisa abstrata, o sentimento de se ter esperança, todavia, é clara a proximidade e a relação de cumplicidade que a autora estabelece com o universo animal no decorrer da trama em trechos como: "Três vezes tentou renitente uma saída entre dois quadros, três vezes teve que retroceder caminho. Custava aprender." (LISPECTOR, 2016, p. 411); “Mas como é bonito o inseto: mais pousa que vive, é um esqueletinho verde, e tem uma forma tão delicada...” (LISPECTOR, 2016, p. 413). Tanto o animal quanto o sentimento se veem vinculados, através da memória da narradora, ao aparecimento de uma esperança (inseto) bem menor, que suscita a seguinte pergunta: o que devemos fazer diante da esperança? Nada? Aquietarmo-nos a fim de que nasça em nós uma flor? Senão, vejamos:

Uma vez, aliás, agora é que me lembro, uma esperança bem menor que esta pousara no meu braço. Não senti nada, de tão leve que era, foi só visualmente que tomei consciência de sua presença. Encabulei com a delicadeza. Eu não mexia o braço e pensei: "e essa agora? que 
devo fazer?" Em verdade nada fiz. Fiquei extremamente quieta como se uma flor tivesse nascido em mim. (LISPECTOR, 2016, p. 413)

Fica evidente que, para ela, são seres que gozam das mesmas percepções de mundo que nós, seres humanos. Nas palavras da professora Maria Esther Maciel percebemos Clarice Lispector inserida num rol de escritores do século XX e animalistas em potencial a quem:

[...] não interessa, propriamente, achar uma ideia no animal, escrever sobre ele e representá-lo literariamente, mas entrar na esfera da intimidade desse outro e tentar extrair, pelos recursos da invenção poética e ficcional, aquilo que o constitui e desafia nosso poder de entendimento. (MACIEL, 2016, p. 94)

Isso fica claro num dado momento do conto "Uma esperança" quando é questionada a inteligência do inseto, e quando sua tomada de decisões é julgada pelos próprios personagens como inferior e/ou duvidosa: "Ela é burrinha, comentou o menino" (LISPECTOR, 1998, p. 92) e em "Está agora procurando outro caminho, olhe, coitada, como ela hesita.” (LISPECTOR, 1998, p. 93). Ou seja, enquanto humanos entendemos o pensamento e a razão como uma característica de nossa espécie ao mesmo tempo em que nos limitamos a projetá-las nos demais viventes.

Por fim, falaremos sobre um dos romances mais densos e aclamados - ainda nos dias de hoje - da escritora, A paixão segundo G.H., cuja publicação se deu em 1964. Nesse livro, a personagem principal encontra-se sozinha (apenas ela e seus pensamentos) no próprio apartamento, angustiada, a vagar da sala de estar para o quarto da empregada, mergulhada num fluxo de consciência que assim se anuncia: “[...] estou procurando, estou procurando. Estou tentando entender" (LISPECTOR, 1991, p. 15).

A partir desse fluxo a personagem G.H. cria um mundo interno extraordinário - de modo que, nada de muito impactante ocorre em toda trama - mas é justamente a densa reflexão interior que se encarrega de prender a atenção do público leitor. Mas a nós, o que 
cabe por ora salientar, é a abordagem que a autora faz, mais uma vez, do entrecruzamento entre humano e animal.

Tal como ocorre no conto "O búfalo", o contato da personagem principal com o animal, no caso, a barata, dá-se através do olhar. É através dele que as naturezas colidem e passam a estabelecer uma comunicação muda. Ao deparar-se com a asquerosidade da barata e a repulsa inicial, a personagem G.H. passa, então, a não mais vê-la apenas, e sim a enxergá-la como o outro de si mesma. Não necessariamente sofrendo o processo de metamorfose que ocorre com Gregor Samsa em A metamorfose. Entretanto, a autora ultrapassa a linha tênue que insiste em inferiorizar e/ou anular quaisquer possibilidades de manifestações sensíveis por parte dos animais com os quais convivemos desde que se tem conhecimento ao dar-lhes protagonismo em muitas de suas obras, demonstrando com tal atitude que

[...] as tentativas literárias de se recuperar o elo intrínseco entre o ser humano e o não humano têm se afirmado no nosso tempo como formas criativas de acesso ao outro lado da fronteira que nos separa do animal e da animalidade. São formas bastante variadas, obviamente, que vão do exercício ficcional à apreensão, pela linguagem, de uma outridade animal, tarefa essa atribuída sobretudo à poesia. Cada uma com sua maneira peculiar de fazer do animal um animal escrito. (MACIEL, 2016, p. 25)

Consoante às diversas demonstrações citadas acima, muitos são os contos de Clarice Lispector que irão tratar sobre a questão animal, e outro conto de extrema relevância que merece ser mencionado ainda nessa seção é intitulado "O ovo e a galinha", publicado em A legião estrangeira, em setembro de 1964.

Assim como em "Uma galinha" e A vida intima de Laura aqui, novamente, podemos estabelecer conexões com a sociedade a partir das imagens do ovo e da galinha, portanto, a fim de não incorrermos em digressões inoportunas será sobre esse aspecto que iremos nos debruçar.

O texto é bastante dinâmico e demanda daquele que lê atenção redobrada no vai e vem que o compõe. O tempo é, predominantemente, psicológico. Ou seja, a narradora o 
assume em seu interior e/ou a partir de suas vivências subjetivas, mas, apesar disso, é possível em alguns momentos identificar tempo e espaço, como em

Olho o ovo na cozinha com atenção superficial para não quebrá-lo, Não toco nele [...] De repente olho o ovo na cozinha e só vejo nele a comida. Não o reconheço, e meu coração bate [...] começo a não poder mais enxergar o ovo. [...] olhei demais um ovo e ele foi me adormecendo, Comecei a falar da galinha e há muito já não estou falando mais da galinha. Mas ainda estou falando do ovo. Pego mais um ovo na cozinha, quebro-lhe casca e forma. [...] Os ovos estalam na frigideira, e mergulhada no sonho preparo o café da manhã. Sem nenhum sendo da realidade, grito pelas crianças que brotam de várias camas, arrastam cadeiras e comem. (LISPECTOR, 2016, p. 304311)

O conto se inicia com a seguinte observação: "De manhã na cozinha sobre a mesa vejo o ovo” (p. 303). Mas o desenrolar da trama nos permite delinear a dominação e/ou opressão - ainda que simbólica - da sociedade para com as mulheres. Isso, claro, quando entendemos o papel da mulher representado pela figura do animal em questão, a galinha.

A forma depreciativa como a narradora a define e resume é denunciativo dessa afirmação em trechos como: "Ovo é a alma da galinha. A galinha é desajeitada. O ovo certo. A galinha assustada. O ovo certo" (p. 304); "A galinha tem o ar constrangido" (p. 306) e "Fora de ser um meio de transporte para o ovo, a galinha é tonta, desocupada e míope" (p. 307).

Tal como fora observado previamente em "Uma galinha" e em A vida intima de Laura aqui, em “O ovo e a galinha”, é perceptível ainda o caráter reducionista muitas vezes atribuído à galinha enquanto fêmea de sua espécie e, (des)afortunadamente, também às mulheres em passagens como: "Para que o ovo atravesse os tempos a galinha existe. Mãe é para isso" (p. 305); "E a galinha? O ovo é o grande sacrifício da galinha. O ovo é a cruz que a galinha carrega na vida [...] A galinha ama o ovo” (p. 306) e, coroando, por fim, sua função de mera depositária: "Mas para a galinha não há jeito: está na sua condição não servir a si própria. Sendo, porém, o seu destino mais importante que ela, e sendo o seu destino o ovo, a sua vida pessoal não nos interessa” (LISPECTOR, 2016, p. 307). 
A noção de serventia da galinha está intrinsecamente ligada ao propósito de pôr ovos, enquanto no universo feminino, estaria ao de procriar/ter filhos. "Para que o ovo use a galinha é que a galinha existe.” (LISPECTOR, 2016, p. 306) Mas, findado esse período de tempo, para ambas, resta o descarte. Descarte esse que pode ser entendido como uma violência - mesmo simbólica - ainda mais nociva que a violência física, pois é naturalizada, embora não devesse sê-lo. É uma das formas que a sociedade patriarcal tem de dominar e tornar insignificantes galinhas e mulheres, algo muito claro nas palavras de Pierre Bourdieu:

A ordem estabelecida, com suas relações de dominação, seus direitos e suas imunidades, seus privilégios e suas injustiças, salvo uns poucos acidentes históricos, perpetue-se apesar de tudo tão facilmente, e que condições de existência das mais intoleráveis possam permanentemente ser vistas como aceitáveis ou até mesmo como naturais. [...] Sempre vi na dominação masculina, o exemplo por excelência desta submissão paradoxal, resultante daquilo que eu chamo de violência simbólica, violência suave, insensível, invisível a suas próprias vítimas. (BOURDIEU, 2002, p. 7)

O penúltimo texto, e último conto, do qual trataremos chama-se "Seco estudos de cavalos", publicado em Onde estivestes de noite no ano de 1974. Este conto versa sobre o processo identitário em curso entre a narradora e o universo animal - através da imagem do cavalo - e isso possibilitará, em certa medida, um intercâmbio com alguns trechos do objeto principal dessa pesquisa, Uma aprendizagem on O livro dos prazeres.

Logo no início da história, a personagem principal expressa o desejo de ter ganhado vida sob outra forma que não a humana, a equina. E isso cria um elo entre mulher e animal:

[...] se pudesse ter escolhido queria ter nascido cavalo. Mas - quem sabe - talvez o cavalo ele-mesmo não sinta o grande símbolo da vida livre que nós sentimos nele. Devo então concluir que o cavalo seria sobretudo para ser sentido por mim? O cavalo representa a animalidade bela e solta do ser humano? O melhor do cavalo e ente humano já tem? Então abdico de ser um cavalo e com glória passo para minha humanidade. O cavalo me indica o que sou. (LISPECTOR, 2016, p. 471) 
A narradora afirma compartilhar, com o animal, características que possibilitam uma conexão entre eles. Ou seja, uma troca entre homem e animal, humano e não-humano pode ser verificada em excertos como: “A forma do cavalo representa o que há de melhor no ser humano. Tenho um cavalo dentro de mim que raramente se exprime. Mas quando vejo outro cavalo então o meu se expressa. Sua forma fala.” (LISPECTOR, 2016, p. 470) e,

Da última vez [...] era tão grande a minha tristeza humana por eu ter sido o que não deveria ser; que jurei que nunca mais. O trote porém continua em mim. Converso, arrumo a casa, sorrio, mas sei que o trote está em mim. Sinto falta dele como quem morre. Não, não posso deixar de ir. (LISPECTOR, 2016, p. 476)

$\mathrm{E}$ isso nos remete ao objeto dessa pesquisa. Em Uma aprendizagem ou O livro dos prazeres, a personagem Loreley - Lóri - assim como a personagem do conto em voga, constata que também compartilha características em comum com o universo animal, e em especial com o cavalo. De acordo com Albuquerque (2002, p. 60), a personagem de Lispector reconhece que há forças não mais humanas e, às quais já não controla, que a conduzem ao universo do outro, não-humano, animal. E, em tom confessional, a protagonista do romance supracitado revela:

Existe um ser que mora dentro de mim como se fosse casa dele, e é. Trata-se de um cavalo preto e lustroso que apesar de inteiramente selvagem - pois nunca morou antes em ninguém nem jamais lhe puseram rédeas nem sela - apesar de inteiramente selvagem tem por isso mesmo uma doçura primeira de quem não tem medo: come às vezes na minha mão. Seu focinho é úmido e fresco. Eu beijo seu focinho. Quando eu morrer, o cavalo preto ficará sem casa e vai sofrer muito. A menos que ele escolha outra casa e que esta outra casa não tenha medo daquilo que é ao mesmo tempo selvagem e suave. Aviso que ele não tem nome: basta chamá-lo e se acerta com seu nome. Ou não se acerta, mas, uma vez chamado com doçura e autoridade, ele vai. Se ele fareja e sente que um corpo-casa é livre, ele trota sem ruídos e vai. Aviso também que não se deve temer o seu relinchar: a gente se engana e pensa que é a gente mesma que está relinchando de prazer ou de cólera, a gente se assusta com o 
excesso de doçura que é isto pela primeira vez. (LISPECTOR, 1998, p. 28-29)

Reconhecimento esse, muito simples de ser percebido também no último texto que iremos mencionar nessa seção. Trata-se da crônica, cujo título é "Não soltar os cavalos" presente em A legião estrangeira, publicada em 1964 e, posteriormente em Para não esquecer, publicado um ano após a morte da autora. Nela, Clarice fala sobre seu processo criativo e, muito rapidamente, faz comparação com o animal cavalo, ao escrever: "Retenho-me, como se retivesse as rédeas de um cavalo que poderia galopar e me levar Deus sabe onde. Eu me guardo” (LISPECTOR, 1992, p. 113).

Nos dois textos, a aliança criada entre as essências humana e animal é reveladora de que em ambas há uma potência selvagem, ao mesmo tempo bruta e doce, representadas pelas imagens da mulher e do animal e indicativa de uma afinidade equina.

Levando-se em conta os argumentos que foram apresentados ao longo dessa seção, podemos afirmar que Clarice Lispector consegue, com maestria, aproximar esferas que, ao longo da história da civilização, os homens tentaram apartar: humano e animal. Haja vista que, por várias vezes fica nítida a identificação de suas personagens humanas com os animais que povoam suas composições.

\section{ZOO WORLD IN CLARICE LISPECTOR}

ABSTRACT: Author of important works that reverberate up to the present, such as Near to the Wild Heart, The Passion According to G.H., The Stream of Life and The Hour of the Star, Clarice Lispector is one of the most relevant names in the Brazilian literature scenario. From her earliest compositions, the author demonstrates an extremely close and empathic relationship with animals, often coming to give them full protagonism. Lispector ingeniously constructs his narratives in such a way as to bring human and animal together, spheres apparently so distinct from each other. We are interested here to analyze how this appears in Uma aprendizagem on O livro dos prazeres - the sixth novel of his career. For this purpose, we will outline a course capable of assuring the reader of the human-animal approach, as well as its recidivisms in the Clarice's writings. To this end, we will address some of her tales, chronicles and books dedicated to children, in which the human is represented through the animal and that, for this reason, we understand as pertinent, given the objectives of this article.

KEYWORDS: Animals; Clarice Lispector; Human; Representation; Uma aprendizagem ou O livro dos prazeres. 


\section{REFERÊNCIAS}

ALBUQUERQUE, Paulo Germano Barrozo de. Mulheres claricianas: imagens amorosas. Rio de Janeiro: Relume Dumará, 2002.

ANDRADE, Maria das Graças Fonseca. Da escrita de si à escrita fora de si: uma leitura de Objeto gritante e Água viva de Clarice Lispector. Tese (Doutorado em Letras: Literatura Brasileira) - Universidade Federal de Minas Gerais. Belo Horizonte, 2007.

BERGER, John. Animais como metáfora. Suplemento literário de Minas Gerais. Belo Horizonte, set./out. 2010, n. 1332, p. 09.

BOURDIEU, Pierre. A dominação masculina. 2. ed. Rio de Janeiro: Bertrand Brasil, 2002.

BRAVO, Álvaro Fernández. Desenjaular o animal. In: MACIEL, Maria Esther (Org.). Pensar/escrever o animal: ensaios de zoopoética e biopolítica. Florianópolis: Editora da UFSC, 2011. p. 221-243.

CHARTIER, Roger. A bistória cultural: entre práticas e representações. Lisboa: Difel, 2002.

CHEVALIER, Jean; GHEERBRANT, Alain. Dicionário de símbolos. 9. ed. Rio de Janeiro: José Olympio, 1995. p. 137-138: Boi, Búfalo.

GARRAMUÑO, Florencia. Região compartilhada: dobras do animal-humano. In: MACIEL, Maria Esther (Org.). Pensar/escrever o animal: ensaios de zoopoética e biopolítica. Florianópolis: Editora da UFSC, 2011. p. 105-116.

HEIDEGGER, Martin. Parmênides. Petrópolis: Vozes; Bragança Paulista: Editora Universitária São Francisco, 2008.

LISPECTOR, Clarice. Outros escritos. Rio de Janeiro: Rocco, 2005.

. A bela e a fera. Rio de Janeiro: Rocco, 1999.

- A Paixão segundo G. H. 15. ed. Rio de Janeiro: Francisco Alves, 1991.

. Felicidade clandestina. 1. ed. Rio de Janeiro: Rocco, 1998.

. A mulher que matou os peixes. 13. ed. Rio de Janeiro: Francisco Alves, 1993.

. A legião estrangeira. 1. ed. Rio de Janeiro: Editora do Autor, 1964.

. Visão do esplendor: impressões leves. Rio de Janeiro: Francisco Alves, 1975. p.137:

Nossa truculência.

- A descoberta do mundo. 4. ed. Rio de Janeiro: Francisco Alves, 1994.

. Para não esquecer. 4. ed. São Paulo: Siciliano, 1992.

. A imitação da rosa. Rio de Janeiro: Artenova, 1973, p. 66-69: Uma galinha. 
. Uma aprendizagem ou O livro dos prazeres. Rio de Janeiro: Rocco, 1998.

- A vida intima de Laura. 12. ed. Rio de Janeiro: Francisco Alves, 1991.

MACIEL, Maria Esther (Org.). Pensar/escrever o animal: ensaios de zoopoética e biopolítica. Florianópolis: Editora da UFSC, 2011.

. Literatura e animalidade. 1. ed. Rio de Janeiro: Civilização Brasileira, 2016.

MOSER, Benjamin (Org.). Clarice Lispector. Todos os contos. 1. ed. Rio de Janeiro: Rocco, 2016. p. 248-257: O búfalo; p. 303-313: O ovo e a galinha; p. 411-413: Uma esperança; p. 470-477: Seco estudos de cavalos.

NASCIMENTO, Evando. Rastros do animal humano - a ficção de Clarice Lispector. In: MACIEL, Maria Esther (Org.). Pensar/ escrever o animal: ensaios de zoopoética e biopolítica. Florianópolis: Editora da UFSC, 2011. p. 117-148.

NUNES, Benedito. O animal e o primitivo: os outros de nossa cultura. In: MACIEL, Maria Esther (Org.). Pensar/ escrever o animal: ensaios de zoopoética e biopolítica. Florianópolis: Editora da UFSC, 2011. p. 13-22.

RODRÍGUEZ, Fermín A. Levar a vida, deixar-se morrer: a virada animal em "El sur" de Jorge Luis Borges. In: MACIEL, Maria Esther (Org.). Pensar/ escrever o animal: ensaios de zoopoética e biopolítica. Florianópolis: Editora da UFSC, 2011. p. 169-175.

Recebido em: 04/10/2019. Aprovado em: 21/01/2020. 